Carpentier, V. (2019 forthcoming) "The History of Higher Education in Modern Europe", in J. L. Rury and E.H. Tamura (eds.) The Oxford Handbook of The History of Education, Oxford University Press, Oxford

\title{
The History of Higher Education in Modern Europe
}

Vincent Carpentier

\begin{abstract}
This chapter explores the history of higher education in Europe by considering three intersected dimensions: the global, national, and local spaces or geography of higher education; the contours of the higher education system regarding access, participation, and institutional differentiation; and the cultural, political, social and economic rationales driving its expansion. Four historical periods are considered: the emergence of the medieval universities and their spread in the feudal order; the demands posed to universities by nation-states and the Enlightenment during the early modern period; the impact of the political and industrial revolutions; and the crisis of mass higher education since 1918. Overall, articulation among the rationales, shapes, and spaces of higher education has changed periodically across history.
\end{abstract}

\section{Introduction}

It is possible to explore the historical development of higher education in Europe by looking at three key intersected dimensions: its spaces, shapes, and rationales. This entails examining chronologies, typologies, and interpretations of expansion with respect to three themes: the links and frictions between the global, national and local spaces or geography of higher education; the shapes or contours of the higher education system in terms of access, participation and institutional differentiation; the connections and tensions between the cultural, political, social, economic rationales driving its expansion. 
Carpentier, V. (2019 forthcoming) "The History of Higher Education in Modern Europe", in J. L. Rury and E.H. Tamura (eds.) The Oxford Handbook of The History of Education, Oxford University Press, Oxford

The history of European higher education can be divided into stages. The first was a shift after the fifteenth century from the spontaneous creation of the early archetypical medieval universities, closely aligned with the professions, to the more measured and territorialized expansion of the late medieval universities. The second was during the early modern period, when the political rationale for universities was strengthened as they became important features of national identity and were increasingly involved in dynastic and religious wars of the time. Next came the late modern era, when successive political and industrial revolutions shifted their political rationale and introduced a socio-economic agenda that transformed universities and revived other forms of higher education. Finally, in the post-1914 era two world wars and the Great Depression led to a profound shift in the alignment of cultural, economic, social and political factors underpinning higher education. This created the conditions for a post-1945 drive to realize mass higher education in conjunction with the rise of a welfare state, the knowledge economy and the cold war. This process has been labeled "massification." The crisis of the early 1970s interrupted this multifaceted development and challenged higher education institutions with respect to funding, access and differentiation. This raised significant tensions between their ideological rationales and organizational dynamics that imperiled continued expansion. These questions remain at the heart of contemporary debates on policy and practice in higher education.

\section{Spaces, Shapes, and Rationales of Higher Education}

The historical study of European higher education has generated many interpretations that reflect its multidimensional and sometimes contested character. This plurality of perspectives underlines the difficulty of offering a holistic account of the origins and consequences of growth in higher education and offers encouragement to consider, when relevant, an interdisciplinary approach to its history. ${ }^{1}$ 
Carpentier, V. (2019 forthcoming) "The History of Higher Education in Modern Europe", in J. L. Rury and E.H. Tamura (eds.) The Oxford Handbook of The History of Education, Oxford University Press, Oxford

The spatial or geographical dimension concerns the expansion of higher education within both its global, national and local contexts. The global dimension has always been present. European higher education has been influenced by higher learning not only in Europe itself, dating to Ancient Greece and Rome, but also from outside, for instance, in the influence of Egyptian, Chinese, Indian and Islamic institutions. European nations have, of course, influenced the trajectory of higher education beyond their borders. Certain other countries have, in return, influenced European higher education more recently. The impact of US higher education is particularly noteworthy. Intra-European exchanges have always been a factor, driven by individual student and staff mobility, institutional collaboration and policy. Although this has contributed to some commonalities in organizational development, European higher education systems have remained linked to national and local priorities. The connections, and indeed the tensions, between these geo-spatial factors have always existed but they have evolved across time. The combination of historical layers and current conditions has led to a "glonacal" (global/national/local) lens on higher education. ${ }^{2}$

A second key dimension to examine is the shapes or institutional contours of higher education expansion. This is evident when considering the alignment, and occasional disjunctions, between patterns of access, participation and institutional differentiation. Clear distinctions between expansion and democratization have been revealed by extensive inequalities in terms of access, participation and outcomes for different social groups, especially regarding social class, gender, ethnicity and other factors). The voices of these groups, previously excluded from historical accounts, have been slowly recovered by studies examining the changing student body. Inequalities of access and participation among groups, within and across countries, are often reflected in differentiation between institutions. Therefore, institutional differences may have contributed to problems in accommodating inequalities. The rise of the medieval university as corporations made the expansion of 
Carpentier, V. (2019 forthcoming) "The History of Higher Education in Modern Europe", in J. L. Rury and E.H. Tamura (eds.) The Oxford Handbook of The History of Education, Oxford University Press, Oxford

European higher education a distinctive phase in the global history of higher education. Arguably, the links between the university and other higher education institutions have differed both across countries and time, resulting in patterns of expansion ranging from highly stratified institutional arrangements to tightly coordinated systems. ${ }^{3}$

A third dimension to consider concerns the different rationales (cultural, political, religious, social, economic, political) associated with various institutional sectors, such as the church, the state, and the economy. For instance, one influential interpretation holds that the expansion of higher education in the nineteenth century was successively driven by politics, economic development and technology. The evolving tensions and connections between these sources of influence reflected a shifting rapport de force or consensus concerning higher education, with implications for funding, equity and quality. ${ }^{4}$

\section{From Higher Learning to the Corporate Medieval University}

The period from the twelfth century to the mid-sixteenth century witnessed the gradual development of early forms of European higher education into universities and their subsequent struggle to achieve autonomy within the varied political agendas of the feudal system. From an early stage, the rise of the university raised questions about the control of higher education institutions with substantial implications for their internal governance. There was a difference, however, between the spontaneous creation of archetypical universities based on the professions and the more territorial development of the late medieval universities. During this time enrolment remained stagnant and was restricted to male students. ${ }^{5}$

The early medieval period was characterized by the spontaneous creation of universities out of existing informal arrangements for higher learning. The university was a product of the middle ages, especially the $12^{\text {th }}$ century, sometimes referred to as the century of corporations. Before being associated with higher education, the term "universitas" was used to define a body with an independent status representing the interests of a group of persons. Universities 
Carpentier, V. (2019 forthcoming) "The History of Higher Education in Modern Europe", in J. L. Rury and E.H. Tamura (eds.) The Oxford Handbook of The History of Education, Oxford University Press, Oxford

therefore emerged as guild or corporation unions, with rights associated with the status of teachers and students, along with their licenses and titles. In a sense, they were corporate developments of previous forms of higher learning, such as the cathedral schools or the Studium Generale. The cathedral schools were traditionally more local and dependent on an individual teacher The Studium Generale prefigured the first medieval universities as communities of teachers and students from various countries travelling across Europe and using Latin as a global language. Moreover, the Studium was an institution created or recognized by religious or political authorities. This highlights the difficulty in precisely establishing the differences between a Studium and a university. Thus, the realization of autonomy and the right to act as a corporate body might have become the most distinctive features of a university at this time. Indeed, the transfer from a Studium Generale to the constitutional development of the university was often a response to local conflicts. The first universities, after all, often had to answer to local political and economic concerns. The knowledge they produced and transmited through the classical curriculum (music, geometry, arithmetic and astronomy) and the areas of higher technical learning (theology, law and medicine) was not only considered as a source of prestige for rulers, but also as training for the xhurch, the state and key professions. ${ }^{6}$

The influence of the local context is exemplified by the creation of the first two archetypical models: the University of Bologna (1088), a guild of students hiring teachers and the University of Paris (1150), a guild of teachers selling their service to students. In the case of Bologna, the student university model was created as a reaction to hostility from its host city. Students (a majority of which were foreign) felt threatened and unprotected by their teachers. As a result, they formed a guild which slowly led them to change the the governance of the university. This model contrasted with the guild of Masters developed in the University of Paris as a response to the local ecclesiastical domination. Another archetypal university 
Carpentier, V. (2019 forthcoming) "The History of Higher Education in Modern Europe", in J. L. Rury and E.H. Tamura (eds.) The Oxford Handbook of The History of Education, Oxford University Press, Oxford

followed in England. Oxford (1167) already existed, but was enhanced by the arrival of masters from Paris. Cambridge (1209) was created by a scission of certain Oxford scholars. Although clearly influenced by the Paris model, both institutions developed their own colleges housing masters and students together. This distinctive English collegiate model was shaped by these institutions. Differing national models of university organization had a strong influence on the second wave of institutional development through the $13^{\text {th }}$ century. Driven by the need to train for the professions. Spain and Portugal created their first universities in Salamanca (1218) and Coimbra (1290); new ones were created in France in Montpellier (1220) and Toulouse (1229) and in Italy in Naples (1224) and Rome (1303). These developments prefigured the increasing tendency toward territorial identification in higher education to come. ${ }^{7}$

After the $14^{\text {th }}$ century, higher education grew and changed. Although the mission of professionalization remained important, universities became increasingly driven by a political rationale. The spontaneous creation of the early universities gave way to a more strategic expansion of late medieval universities, driven by power struggles in the feudal order. This led to a substantial increase in their number, from 20 to 70 between 1300 and 1500 . Universities had to find their place in the midst of political and religious conflict. . This trend was accentuated by numerous political skirmishes and wars, and a schism in the Catholic Church over the Avignon papacy (1378-1418), leading many scholars to flee their countries. This difficult context led to the creation of new universities all over Europe, based on prior models of the early institutions. Accordingly, the studia of Northern and southern Europe were respectively influenced by Paris and Bologna. New development took place in Central and Eastern Europe with the creation of the University of Prague (1348) by King Charles II, who sought to make that city the center of the German Empire. Prague was followed by the Universities of Vienna (1367), Pecs (1367), Heidelberg (1387) and Cologne (1388). A web of universities gradually covered all Europe with the creation of the first such institutions in 
Carpentier, V. (2019 forthcoming) "The History of Higher Education in Modern Europe", in J. L. Rury and E.H. Tamura (eds.) The Oxford Handbook of The History of Education, Oxford University Press, Oxford

Scotland with St Andrews (1409), Glasgow (1451) and Aberdeen (1495) and in the Nordic countries with the Universities of Uppsala (1477) and Copenhagen (1479). ${ }^{8}$

A key change in higher education during this period - and a direct result of the process of national and regional development - was a moderation in the international identity of the first universities. The early forms of international mobility that had contributed to a proto European higher system gradually weakened. The international character of universities slowly diminished as they became increasingly influenced by local political power. This trend intensified in the early modern period, which was characterized by a shift from the local feudal order to the construction of nation states. ${ }^{9}$

\section{From Nationalisation to Enlightnment: Higher Education in the Early Modern Period}

The early modern period in European history can be divided into two eras with respect to higher education. Until the mid- $17^{\text {th }}$ century, a substantial increase in the number of universities was driven by a process of nationalization and religious competition, and the emergence of an increasingly elite student population. After the mid- $17^{\text {th }}$ century, a slowdown in the university expansion and the revival of other forms of higher education became associated with slower national development and new demands for more secular, professional and scientific education associated to the emerging enlightenment. Three words describe aptly the above changes: "expansion, differentiation, and professionalization."10

Although the evidence should be interpreted with caution, studies show an increase in enrolment from the mid- $16^{\text {th }}$ to the mid- $17^{\text {th }}$ centuries. For instance, admissions in Oxford and Cambridge rose from 100 in 1550 to 1000 in 1650. From 1575/1600 to 1650 the percentages of the age cohort traditionally associated with higher education rose from $1.2 \%$ to $2.8 \%$ in Germany, from $0.2 \%$ to $0.7 \%$ in the Dutch republic and from $1.4 \%$ to $2.4 \%$ in Portugal. Such expansion can be interpreted as the combined result of continued national development and religious conflict, which both led the church and the state to seek the support of universities. 
Carpentier, V. (2019 forthcoming) "The History of Higher Education in Modern Europe", in J. L. Rury and E.H. Tamura (eds.) The Oxford Handbook of The History of Education, Oxford University Press, Oxford

Indeed, the $16^{\text {th }}$ and $17^{\text {th }}$ centuries witnessed a sharp acceleration of the creation or consolidation of nation-states in Spain, Russia, France, Italy, Prussia and Sweden. The increased number of universities has also been linked to the schism between Catholics and Protestants during the Reformation 1517-1648. Universities were factors in the political and religious conflicts of the $16^{\text {th }}$ and $17^{\text {th }}$ centuries". This trend further weakened the international character of early universities, with church and state inhibiting the mobility of scholars and students. ${ }^{11}$

Another notable characteristic of the early modern era is the emergence of a new social rationale of higher education. This may have been linked to elitism, as suggested by changes in enrolment. Institutions became more aristocratic, preoccupied by a new social function of educating the elites. Moreover, an embryonic cultural shift was also taking place, under the influence of the Italian Renaissance and its revival of humanism based on reasoning and empirical evidence. These new ideas spurred debates regarding the curriculum and new disciplines suggesting the importance of practice alongside theory, and efforts to revive the professional side of universities. This set the stage for additional challenges to universities with the arrival of the enlightenment.

The development of higher education was not always linear, as shown by the decline of university enrolment in the second part of the $17^{\text {th }}$ century, observed in most European countries. From 1650 to 1750 , the age group participation fell from $2.8 \%$ to $1.7 \%$ in the German Empire and from $1.8 \%$ to $1.5 \%$ in the Dutch Republic. New admissions in Oxford and Cambridge from the mid- $17^{\text {th }}$ to the mid- $18^{\text {th }}$ century fell from 1000 students to around 100 (roughly the level of the mid- $16^{\text {th }}$ century). Many reasons have been offered to explain such decline. A slowdown in the religious competition that drove the expansion of higher education cannot be underestimated. A second factor was the emergence in the late $17^{\text {th }}$ century of the Enlightenment, driven by the humanist ideals inherited from the renaissance, and characterized 
Carpentier, V. (2019 forthcoming) "The History of Higher Education in Modern Europe", in J. L. Rury and E.H. Tamura (eds.) The Oxford Handbook of The History of Education, Oxford University Press, Oxford

by an interest in science, rationality, discovery and novelty that universities did not usually address at the time. ${ }^{12}$

The Enlightenment reshaped higher education in two ways. First, it forced universities to change. In certain cases, it contributed to reform. For instance, universities were important drivers of the Scottish enlightenment. Secondly, the Enlightenment offered teaching and especially scholarship outside the university with such new or re-emerging institutions as learned societies or academies. Learned academies were first created in Italy in the early $17^{\text {th }}$, soon followed by French and British counterparts. The creation of societies, such as the encyclopaedists, but also formal higher education institutions such as the Grandes Ecoles, indicated that a scientific revolution was taking place outside the university in most countries, with Scotland and Holland representing notable exceptions. ${ }^{13}$

\section{Revolution, Unrest, Mutation and the Creation of the New Models of European Higher Education, 1789-1914}

The long nineteenth century was characterized by political turbulence across Europe, strengthening the partisan and economic rationales behind higher education. The revolutions and crises that punctuated the late eighteenth and early nineteenth centuries offered a mix of threats and opportunities for universities. Overall, the period led to further differentiation of institutions and the development or reinforcement of national models of higher education, including the research orientated German model, the centralized French model and the collegial English model. The British Industrial Revolution and the French political Revolution broke the political, social and economic order of the ancien régime. As a result, most European countries were rocked by political, social and economic turmoil, with serious implications for the universities and other higher education institutions. In certain respects, this era, characterized as an Age of Revolution, marked the birth of modern higher education systems. ${ }^{14}$ 
Carpentier, V. (2019 forthcoming) "The History of Higher Education in Modern Europe", in J. L. Rury and E.H. Tamura (eds.) The Oxford Handbook of The History of Education, Oxford University Press, Oxford

In one of the period's most notable developments, the French Revolution contributed to diversification, centralisation and professionalization in higher education. The revolutionaries distrusted the old universities and their association with the state and the Church. They legislated the Loi le Chapelier, which suppressed corporations in 1791 and led to the abolition of the universities two years later. Meanwhile, they increased the number of the more professionally orientated Grandes Ecoles such as the Ecole Polytechnique and Ecole Normale Supérieure. Thus, the higher education system became more differentiated, although also unstable in the wake of revolutionary and counter-revolutionary episodes. For example, the Revolution suppressed the corporatist universities but Napoleon recreated them in 1806 under the auspices of the Imperial University, a single institution controlling regional faculties across the country. This was the first European attempt to develop a national system of higher education, centralized and utilitarian, catering to key military and civil occupations. Following the 1848 Revolution, the Second Republic again suppressed the universities until the Second Empire revived them in 1896, transforming the faculties into regional universities. The spread of the French Revolution's ideal, through inspiration or force, impacted higher education across Europe. The influence of its anti-university posture was revealed by a fall of the number of universities in Europe from 133 to 83 between 1789 and 1815. The Napoleonic professionalization agenda and its focus on developing vocationally orientated institutions was evident in occupied Italy, with the creation of its first Grande Ecole, the Scuola Normale Superiore di Pisa in 1810. The centralized Napoleonic model also influenced national higher education systems in Spain (1857) and across Italy (1859). The 1806 defeat at the hands of Napoleon contributed to the creation of the University of Berlin in 1810 and the rise of the Humboldtian model and its emphasis on research and scholarship, the unity of teaching and research, and a combination of academic freedom and state administration and funding. ${ }^{15}$ 
Carpentier, V. (2019 forthcoming) "The History of Higher Education in Modern Europe", in J. L. Rury and E.H. Tamura (eds.) The Oxford Handbook of The History of Education, Oxford University Press, Oxford

In Britain, these changes were less dramatic but still conspicuous. The needs for plurality led to the creation of the London University in 1826, a secular and utilitarian university that, unlike Oxford and Cambridge, accepted students outside the Church of England. Diversity was further enhanced with the transformation of the London University into University College London in 1836, which joined the new federal University of London with Kings College (1829) and the creation of the University of Durham (1832). Although political and religious factors clearly dominated the British higher education agenda, an economic rationale related to science and professionalization was emerging, albeit at a slower pace than elsewhere. Indeed, the English model, symbolized by Cardinal Newman's ideal of the university (1850), focused on the formation of the students' religious and moral character rather than on vocational training or research. Another factor was the English universities' close connections to the country's growing Empire, rather than the needs of industry. Indeed, the first British industrial revolution (1760-1820) was primarily based upon textiles, which relied upon practical knowledge from individual innovators rather than formalized knowledge from academic or scientific inquiry. Most inventions of the era were developed outside the university, and training workers typically did not require higher education. But from the 1820s onwards, English universities were often criticized for their lack of commitment to research and scholarship focused on practical problems. Although some forms of vocational higher learning developed at the time, such the Mechanics Institutes, there was an emerging view that higher education had to change by giving more attention to science alongside the humanities. However, it would take an additional industrial revolution to make this a reality. ${ }^{16}$

The second part of the $19^{\text {th }}$ century witnessed major interrelated changes, such as the Second Industrial Revolution, a long depression and widening colonization. All these developments had compelling implications for higher education, including a strengthened case for instruction and research in science, and the early signs of a social justice agenda related to 
Carpentier, V. (2019 forthcoming) "The History of Higher Education in Modern Europe", in J. L. Rury and E.H. Tamura (eds.) The Oxford Handbook of The History of Education, Oxford University Press, Oxford

social class and gender. The second industrial revolution (1860-1914) entailed production processes associated with electricity and chemistry, requiring higher level of technological innovation and formalized and systematic knowledge. Moreover, it was taking place in a context of an increasing international competition between Britain, the USA, Germany and France. This new race for innovation contributed to the emergence of the research university and a new form of stratification of higher education systems, differentiating classical and technical institutions around Europe. The Humboldtian model complemented its focus on university research and scholarship with new technical high schools between 1840 and 1890 . France increased the number of Grandes Ecoles and introduced university reforms seeking to assimilate the German emphasis on science and scholarship, which had been interpreted as a key reason behind the defeat in 1870 . Sweden developed new universities specializing in science in Stockholm (1878) and Gothenburg (1891). These changes coincided with reforms made by a key economic competitor outside Europe. The well-known Morrill Act 1862 and 1892 in the USA used federal land grant as financial endowment for new agricultural and technical institutions. It took time for Britain to join the trend. Five Welsh universities were created from 1865 to 1882 and the first annual treasury grant to University Colleges was legislated in 1889. In England the development of civic universities was a combined response to a quest of the middle class for a higher social status and the search for a curriculum addressing new technical or industrial needs. Six civic universities were created between 1900 and 1909 in Birmingham, Liverpool, Manchester, Leeds, Sheffield and Bristol. Despite this progress, there was a lack in state support in Britain compared to Germany and France. Such differences in investment has been linked to a shift in the balance of global economic strength at the eve of the First World War and thereafter. ${ }^{17}$

Meanwhile, a social rationale for higher education also was slowly emerging. Civic university reform and the heritage of the Revolutionary Era had limited universities' to largely 
Carpentier, V. (2019 forthcoming) "The History of Higher Education in Modern Europe", in J. L. Rury and E.H. Tamura (eds.) The Oxford Handbook of The History of Education, Oxford University Press, Oxford

serving a bourgeois clientel. The working class was still left out of them, contributing to the emergence of popular education movements. These fostered, from the 1870 s onwards, the development of University Extension in the UK and similar institutions across Europe, such as the Universités Populaires in France and Belgium from 1899. While these initiatives were locally successful, however, they remained limited in scope. Another dimension of the social justice agenda was related to women's access to higher education. A movement addressing this started in Switzerland in 1867, and one appeared in Sweden in 1873. In France, the first degree obtained by women dates to 1875 . In the UK, the creation of colleges for women and a slow increase of access to mainstream universities can be traced to the 1850 s although women had to wait until 1878 to obtain degrees from the University of London and 1892 from the Scottish universities. Degrees were awarded to women at Oxford beginning in 1920 and Cambridge in 1948. The drive toward gender equity was a long process with uneven progress across Europe. The proportion of women students, however, kept rising, reaching $27 \%$ in the UK on the eve of the First World War but only $7 \%$ in France and Germany and 6\% in Italy. ${ }^{18}$

\section{The Origin, Development, and Crisis of Massification}

A process of growing mass participation in higher education, mainly led by public institutions, took place in Europe after 1945. It was clearly the result of long-term transformations in society and the economy, combined with profound changes triggered by two global wars and the great depression in the first half of the twentieth century. This process was altered by the socio-economic crisis of 1973, which did not halt expansion but produced tensions in the existing rationales, spaces and shapes of higher education.

The first half of the twentieth century was a time of great instability that culminated in a paradigm shift for higher education. This was driven by the convergence of its cultural, economic, political and social rationales following the two world wars and the Great 
Carpentier, V. (2019 forthcoming) "The History of Higher Education in Modern Europe", in J. L. Rury and E.H. Tamura (eds.) The Oxford Handbook of The History of Education, Oxford University Press, Oxford

Depression. The disruptions to higher education institutions caused by the First World War coincided with an increased demand for contributions to the war effort. The mission of the university was important both for training and applied research for military purposes. The strategic role of higher education was acknowledged in the creation of new institutions, such as the British University Grants Committee in 1919. Temporary funding cuts during the Great Depression did not reverse the overall trend towards a greater public engagement. The Second World War, a conflict with fighting and destruction on a scale never seen, led to disruptions and closures of institutions, pressure on funding, staff and students enrollment in the military, and ideological pressure on the curriculum. However, once again, despite all these constraints and distractions, higher education institutions remained engaged on both the technological front, assisting research in key sectors such as enginery, metallurgy and chemistry and on the ideological front in debating fascist, communist and capitalist ideas. ${ }^{19}$

The long-term legacy of the World Wars and the Great Depression was to enhance the various rationales for higher education, embracing its teaching, research and service functions. More importantly, it helped to connect them, leading to the post 1945 process of massification. First, the widespread social, economic and cultural destruction of the war era strengthened the social rationale for education. The fact that men and women from all strata of society were engaged together in a common existential struggle helped to instill new democratic viewpoints that favored progressive and inclusive educational policy. A second key outcome was the reaffirmation of the economic rationale for higher education. Indeed, the importance of research and innovation and the training of the workforce were made clear, prefiguring what would later become a human capital agenda for most European nations. Another economic effect of the wars, and indeed of the depression also, was to make the public funding of social systems more acceptable, with a more welcoming attitude towards taxation and the need to address inequality. A third effect was the strengthening of the political or geopolitical rationale 
Carpentier, V. (2019 forthcoming) "The History of Higher Education in Modern Europe", in J. L. Rury and E.H. Tamura (eds.) The Oxford Handbook of The History of Education, Oxford University Press, Oxford

for higher education. The wars and the depression initiated an ideological battle between the capitalist and communist political systems at the heart of the cold war, in which higher education systems played a key role. ${ }^{20}$

These three legacies of the depression and war are important to understanding the postwar era, characterized by developments such as the rise of the welfare state, the knowledge economy, and the decolonization process. Added to this was the Cold War, which also impacted higher education. This period, and especially the 1960s, is considered a time of massification, with significant growth in enrolment and increased resources (despite persistent inequalities of access and participation).

A first phase of massification of higher education took place between 1945 and 1973, during which the alignment of the social, economic, political and geopolitical rationales made a strong case for considering higher education a public good. This justified state intervention. In a sense, the welfare state and the human capital agenda for economic development coincided. Tax funded higher education became an integral part of the post-war industrial economy, characterized by a virtuous cycle in which productivity gains were redistributed through progressive wage policies. At the same time, public spending is turned to social programs, contributing in return to new sources of productivity. In most European countries, massification took place under public funded and/or publicly controlled systems of higher education. For many countries such as the Nordic group or those which adopted the Humboltian or Napoleonic models, this development only meant an acceleration of existing trends. For others, it changed the shape of higher education. For instance, in the UK, new public provision and increased public funding meant that government contributions to university income rose from $50 \%$ to $90 \%$ between 1945 and 1973. For other reasons, state intervention was also strong in certain autocracies in the West, such as Spain, Portugal and Greece, and the communist regimes in Central and Eastern Europe. This increase of state support for higher 
Carpentier, V. (2019 forthcoming) "The History of Higher Education in Modern Europe", in J. L. Rury and E.H. Tamura (eds.) The Oxford Handbook of The History of Education, Oxford University Press, Oxford

education in both East and West was accelerated by its strategic role of knowledge in the Cold War. ${ }^{21}$

This conjunction of rationales boosted investment and drastically modified both the size and shape of higher education. The number of universities in Europe increased from 204 to 524 from 1949 to 1984 . Enrollment of 20- to 24-year-olds also increased in most western European countries, from about 4.5 percent in 1950 , to 6.4 percent in 1960 , and 17.4 percent in 1975. In many countries, the number of staff increased sufficiently to maintain the student/staff ration, although in others is resulted in a lower student/staff ratio. The drive towards massification was substantial but could not entirely mask the persistence of inequalities in access and participation. For example, the rise of the proportion of women student from $21 \%$ to $33 \%$ from 1951 to 1974 in the UK shows that gender access was a key driver of expansion but also reveals that parity was far from achieved. A similar observation applies to lower income and minority ethnic groups, whose numbers and proportions increased but remained underrepresented, especially in elitist institutions. Similar conclusions can be made for France. ${ }^{22}$

Another key change in the shape of the system was the increase, in most countries, of institutional differentiation or stratification to enact the expansion agenda. In Britain, the government implemented the expansion recommended by the 1963 Robbins Report, creating new universities and a new public sector of higher education, including polytechnics and colleges of education. The post-war French plan for expansion complemented the new universities and Grandes Ecoles with the creation of Instituts Universitaires de Technologie, delivering 2 years higher education diplomas and new research centers outside universities. Differentiation between universities and technical high schools was also the basis for the expansion of Dutch and German higher education. A key question thus is the extent to which diversification represented greater variety or a new manifestation of inequalities between social 
Carpentier, V. (2019 forthcoming) "The History of Higher Education in Modern Europe", in J. L. Rury and E.H. Tamura (eds.) The Oxford Handbook of The History of Education, Oxford University Press, Oxford

groups. It appears that countries like Britain and France limited the extent of the stratification of their institutions, while Germany and the Netherlands held to a single level, and Sweden in general maintained one level. The expansion through differentiation clearly had dissimilar effects on inequality in different countries. The question is whether this stratification was functional or simply reflected social stratification. Overall, during this first phase of massification (1945-1973), the organization of higher education became increasingly national and linked to the maintenance of welfare states. The creation of the European system was eventually characterized by laissez-faire policies in relation to higher education. This left important international dimensions of higher education (such as student mobility) to be expressed in geopolitical terms, associated with former colonies and the Cold War. In sum, the end of the 1960s saw the massification of higher education that was driven by a robust socioeconomic rationale, shaped by an institutional differentiation, and supported by significant public investment in the growth of national systems of higher education. ${ }^{23}$

Most of this changed with the social, economic and political crises during the 1970s, which directly and indirectly altered the rationales, spaces and shapes of higher education in most countries. A second phase of massification thus took place in a context marked by rapid and fundamental transformations. The decline of the welfare states, the end of the cold war, the emergence of new global powers and the apparition of new technologies challenged the arrangement of higher education that had developed after the Second World War. The process of massification during that period reached a new level but inequalities remained. Participation rates increased dramatically overall and many countries began to approach the $50 \%$ threshold of universal higher education. Gender parity has been achieved in most countries, although significant inequalities were still in place. The gaps between socio-economic groups narrowed but remained important in regard to access, participation and institutional differentiation. These mixed results, combining continuous expansion with unfinished democratization, may have 
Carpentier, V. (2019 forthcoming) "The History of Higher Education in Modern Europe", in J. L. Rury and E.H. Tamura (eds.) The Oxford Handbook of The History of Education, Oxford University Press, Oxford

been connected with tensions between massification and funding priorities. The economic crisis of the 1970s not only strengthened the economic rationale for higher education, but also transformed its focus by giving more prominence to a low taxation agenda, alongside (or perhaps against) the traditional human capital agenda. This shift in focus led policy makers to overlook other non-economic rationales and to underestimate social benefits. A shift in the social function of higher education slowly weakened its case for being considered a public good. Thus, the 1970s and beyond crisis produced major constraints on public resources to higher education, often at odds with the agenda of increasing access. These developments generated increasing tensions between the goals of greater funding, equity and quality, producing great pressure to reshape the system. For some countries, the limitation of public spending meant a slowdown of expansion, an increased stratification or (and) serious issues about the quality of the provision. In many countries, austerity led to the development of new public management reforms borrowed from the private sector, which have been strongly debated with respect to their applicability to education and the resulting tensions between accountability and professional autonomy. ${ }^{24}$

Another change resulting from the crisis was the introduction in some countries of private funding to compensate for the retreat of state support. This includes the implementation of cost-sharing policies (increase in fees for international or (and) domestic students and donations) and the introduction of other sources of private funding, such as commercial activities. There have been important debates about the suitability and sustainability of these changes. Key questions include whether more private resources generate additional resources or only (partially) substitute for declining public funding, and their effects on access and participation. There are also concerns about the imperfections of the higher education market, and the impact of a shift in the role of students from co-producers to customers. 
Carpentier, V. (2019 forthcoming) "The History of Higher Education in Modern Europe", in J. L. Rury and E.H. Tamura (eds.) The Oxford Handbook of The History of Education, Oxford University Press, Oxford

Another change in the shape of the higher education system includes the emergence (or the return) of private (or not for profit) providers and changes in provision with online providers beyond such traditional institutions as the Open University. Debates about the impact of private provisions mirror those concerning private funding. A key question is whether the increase in private funding and the new types of provisions reflect an acceleration of inequality or a movement toward greater diversity. ${ }^{25}$

These radical changes in the shape of the system cannot be dissociated from substantial transformations of the geography of higher education. Global changes strongly impacting higher education include the end of the cold war, the construction of a pan-European model in higher education, as well as the acceleration of a particular form of globalization characterized by neo-liberalism and the emergence of new players (such as China, India, Brazil and Russia). Global forces accelerated (rather than created) the transformations that started at national level at the end of the 1970s in two ways. First, the competitive emphasis of the current form of economic globalization, along with greater control of taxation, increased the pressure on public funding in higher education. Secondly, the General Agreement on Trade in Services (GATS) set up in 1995 abbetted the development of a global market in higher education encouraging competition within and across countries.

Additionally, globalization has accelerated and transformed the internationalization of higher education. Although universities have always been international, there also has been an acceleration of mobility for student and staff and a rise in new types of mobility including movement to physical (programs or campus) and virtual (online) provision of cross-border higher education. The degree of engagement with internationalization has increased everywhere but the forms of that engagement and the rationales behind it have differed among countries. Although the political and cultural rationales are still present, the need to generate additional income to counter the reduction of public funding has increasingly been a critical 
Carpentier, V. (2019 forthcoming) "The History of Higher Education in Modern Europe", in J. L. Rury and E.H. Tamura (eds.) The Oxford Handbook of The History of Education, Oxford University Press, Oxford

factor for attracting international students and developing offshore campuses and distance learning. The impact of these developments on inequalities within and between countries has been debated. The direction of global higher education will contribute, alongside other social and economic actors, to addressing the interrelated issues of economic growth, equity, democracy and sustainability.

Arguably, the development of the European higher education has had an influence on higher education elsewhere. It involves a mix of rationales including a closer political integration of the member states, the development of a knowledge economy and social cohesion. European integration has also influenced the reshaping of the higher education landscape in two ways. First of all, it has increased the connections among higher education systems through the European Union (EU) funding of research collaborations and programs promoting student and staff mobility. For instance, the number of mobile students under the ERASMUS program, a student-exchange program, has increased from 3000 to 200,000 since 1987.

Secondly, greater European cooperation has reshaped national higher education systems. For example, the Bologna process was signed in 1999 by the education ministers of 29 European countries (the process is not an EU policy) to increase the convergence between their higher education systems (a common three cycle system, harmonization of quality assurance and transfer of credit and recognition of qualification). Since then, the number of signatories has kept on increasing and a consistent flow of initiatives has been deployed to develop the European Higher Education Area.

The differences between national models of higher education might explain why the policy towards convergence has been diversely interpreted and debated across countries. The impact of the Bologna process differed across countries, because of variation their national systems. The rationale behind the European policy agenda has also been widely debated. Some 
Carpentier, V. (2019 forthcoming) "The History of Higher Education in Modern Europe", in J. L. Rury and E.H. Tamura (eds.) The Oxford Handbook of The History of Education, Oxford University Press, Oxford

welcomed an overdue process of economic and political harmonization, while others considered it as a disguised attempt to drive the marketization agenda. The latter view highlighted connections between the Bologna process and the EU Lisbon Strategy regarding economic development (2000) as evidence of a predominantly economic rationale. However, European cooperation should not be seen as distinct from other influences on higher education, and in many instances has been seen as a driver of national reforms.. ${ }^{26}$

\section{Conclusion}

Not surprisingly, the history of higher education in Europe reveals a variety of changes and continuities. Of course, the expansion has been massive and provoked substantial qualitative transformations since the Middle Ages, which make the historical comparison of higher education systems across time periods difficult. Nevertheless, the long view reveals recurrent trends, questions and mechanisms which are worth considering.

First of all, the historical perspective shows that political, cultural, social and economic rationales have always been present, but also identifies recurrent historical shifts in their connections and order of importance. The economic rationale is not new and can be traced back to the beginning of the university with the idea of professionalization. It then took a back seat during the more humanistic/socratic era before assuming a new dimension during the second Industrial Revolution of the late $19^{\text {th }}$ century, and becoming a key driver of the post war national higher education policy. However, although the rationales have been in competition, it is important that they remain aligned to reflect the multidimensionality of higher education. There is a risk that the dominance of the economic and financial rationales can develop hegemonically, weakening the cultural, political and social rationales which remain important.

A second lesson from the historical perspective is that higher education has always been influenced by its global, national and local dimensions. Higher education institutions were from the beginning local institutions with international reach, before becoming increasingly part of 
Carpentier, V. (2019 forthcoming) "The History of Higher Education in Modern Europe", in J. L. Rury and E.H. Tamura (eds.) The Oxford Handbook of The History of Education, Oxford University Press, Oxford

nation-building projects. Of course, the level of internationalization is far more important today and a shift to global practices is emerging.

Third, the long view points at a mix of changes and continuities in relation to the shape of higher education which reflect the connections and potential tensions between expansion and democratization.

Overall, the long-term perspective shows that the dynamics of articulation between the rationales, shapes and spaces of higher education were not stable and that the consensuses which drove them have changed regularly across history. Of course, shifting rationales, spaces and shapes are the consequences of larger social, economic and political forces that are beyond the reach of higher education policy alone. 
Carpentier, V. (2019 forthcoming) "The History of Higher Education in Modern Europe", in J. L. Rury and E.H. Tamura (eds.) The Oxford Handbook of The History of Education, Oxford University Press, Oxford

\section{Bibliography}

Aldrich, Richard. "The Three Duties of the Historian of Education." History of Education, 32/2 (2003): 133-143.

Anderson, Robert Dean. European Universities from the Enlightenment to 1914. Oxford: Oxford University Press, 2004.

Carpentier, Vincent. "Public-Private Substitution in Higher Education: Has CostSharing Gone Too Far?” Higher Education Quarterly, 66/4 (2012): 363-390.

Charle, Chistophe and Verger, Jacques. Histoire des Universités. XIIème-XXIème siècles. Paris: Presses Universitaires de France, 2012.

Cobban, Alan. B. The Medieval Universities. London: Methuen, 1975.

De Ridder-Symoens, H. A History of the University in Europe. Volume I: Universities in the Middle Ages. Cambridge: Cambridge University Press, 1992.

Dyhouse, Carol. Students: A gendered history. London: Routledge, 2006.

Lowe, Roy. "Structural Change in English Higher Education, 1870-1920.” In The Rise of the Modern Educational System, edited by D. K. Müller, F. Ringer and B. Simon, pp.173178. Cambridge: Cambridge University Press, 1987.

Musselin, Christine. The Long March of French Universities. London: Taylor \& Francis, 2004.

Perkin, Harold. "History of Universities." in International Handbook of Higher Education, edited by J.J.F. Forest and P.G. Altbach , pp. 159-205. Dordrecht: Springer, 2006. Rashdall, Hastings. "The Universities of Europe in the Middle Ages, Vol.1". $2^{\text {nd }}$ edition by Frederick M. Powicke and Alfred B. Emden, . Oxford: Oxford University Press, 1936.

Sanderson, Michael. The Universities and British Industry 1850-1970. London: Routledge \& Kegan Paul, 1972. 
Carpentier, V. (2019 forthcoming) "The History of Higher Education in Modern Europe", in J. L. Rury and E.H. Tamura (eds.) The Oxford Handbook of The History of Education, Oxford University Press, Oxford

Silver, Harold. "Things Change but Names Remain the Same: Higher education historiography'. History of Education. 35/1 (2006): 121-140.

Trow, Martin. Problems in the Transition from Elite to Mass Higher Education. Paris: OECD, 1974.

Watson, David. The Question of Conscience: higher education and personal responsibility. London: Institute of Education Press, 2014. 
Carpentier, V. (2019 forthcoming) "The History of Higher Education in Modern Europe", in J. L. Rury and E.H. Tamura (eds.) The Oxford Handbook of The History of Education, Oxford University Press, Oxford

${ }^{1}$ Joyce. Goodman and Jane Martin. "Editorial: History of Education-Defining a Field".History of Education, 33/1 (2004): 1-10. Vincent Carpentier. "Quantitativeources for the History of Education". History of Education, 37/5 (2008): 701-720.

${ }^{2}$ See Simon Marginson and Gary Rhoades, "Beyond National States, Markets, and Systems of Higher Education: A Glonacal Agency Heuristic” Higher Education, 43 (2002): 281-309. ${ }^{3}$ Examples include Pierre Bourdieu and Jean-Claude Passeron, Les héritiers, les étudiants et la culture (Paris: Editions de Minuit, 1964); Diane Reay, Miriam David and Stephen Ball, Degrees of Choice: Class, Race, Gender and Higher Education (Stoke-on-Trent: Trentham Books, 2005); Carol Dyhouse, Students: a gendered history (London: Routledge, 2006); Roy Lowe, "Structural Change in English Higher Education, 1870-1920" in Detlef K. Müller, , Fritz Ringer and Brian Simon (Eds), The Rise of the Modern Educational System (Cambridge: Cambridge University Press, 1987), pp.173-178; Harold. Silver, “Things Change but Names Remain the Same: Higher education historiography”. History of Education, 35/1 (2006): 121-140. Burton R. Clark, The Higher Education System: Academic Organisation in Cross-National Perspective (Berkeley and Los Angeles, University of California Press, 1983). On the expansion of higher education, see Martin Trow, Problems in the Transition from Elite to Mass Higher Education (Paris: OECD, 1974); Ulrich Teichler, "Diversification? Trends and explanations of the shape and size of higher education". Higher Education, 56 (2008): p. 354. Harold Perkin, “History of Universities” in James J.F. Forest and Philip G. Altbach (eds), International Handbook of Higher Education (Dordrecht: Springer, 2006), p. 159; David Watson, The Question of Conscience: Higher education and personal responsibility (London: Institute of Education Press, 2014), pp. 2-10. See also Jussi Välimaa, “On Traditions and Historical Layers in Higher Education” in Jürgen Enders and 
Carpentier, V. (2019 forthcoming) "The History of Higher Education in Modern Europe", in J. L. Rury and E.H. Tamura (eds.) The Oxford Handbook of The History of Education, Oxford University Press, Oxford

Frans Van Vught, eds., Towards a Cartography of Higher Education Policy Change:

Festschrift in Honour of Guy Neave Enschede, Netherlands: 2007).

${ }^{4}$ Peter Scott, The Meanings of Mass Higher Education (Buckingham: Society for Research into Higher Education (SRHE) and Open University Press, 1995); Vincent Carpentier, "Public-Private Substitution in Higher Education: Has Cost-Sharing Gone Too Far?" Higher Education Quarterly, 66/4 (2012), p .372.

${ }^{5}$ Perkin, 161.

${ }^{6}$ Paul F. Grendler, The Universities of the Italian Renaissance (Baltimore: Johns Hopkins University Press, 2002); Alan B. Cobban, The Medieval Universities (London: Methuen and Co, 1975), p. 23; Olaf Pedersen, The First Universities (Cambridge: Cambridge University Press, 1997), p. 154; Verger, "Patterns" in Walter Rüegg (Ed.), A History of the University in Europe: Vol. 1. Universities in the Middle Ages (Cambridge: Cambridge University Press, 1992), p. 35; Hastings Rashdall, "The Universities of Europe in the Middle Ages, Vol.1". $2^{\text {nd }}$ edition by Frederick M. Powicke and Alfred B. Emden (Oxford, Oxford University Press, 1936), pp. 1-10; Cobban, p. 75.

${ }^{7}$ Ted. Tapper and David Palfreyman, Reshaping the University: The rise of the regulated market in higher education (Oxford: Oxford University Press, 2014), p. 23.

${ }^{8}$ Cobban, p. 116; Perkin, p.159; Cobban, p. 120.

${ }^{9}$ Jeroen Huisman and Frans van Vught, "Diversity in European Higher Education: Historical Trends and Current Policies" in Frans van Vught (ed.), Mapping the Higher Education Landscape. Higher Education Dynamics (Dordrecht: Springer, 2009), pp. 17-38; Cobban, p. 118.

${ }^{10}$ Quote from Willem Frijhoff, "Patterns”, in Hilde de Ridder-Symoens (ed.), A History of the University in Europe: Vol. 2. Universities in early modern Europe (1500-1800) (Cambridge: Cambridge University Press, 1996), p. 79. 
Carpentier, V. (2019 forthcoming) "The History of Higher Education in Modern Europe", in J. L. Rury and E.H. Tamura (eds.) The Oxford Handbook of The History of Education, Oxford University Press, Oxford

${ }^{11}$ Lawrence Stone, The University in Society, vol.1 (London: Oxford University Press, 1975), p. 6; Maria Rosa Di Simone, “Admission" in Hilde de Ridder-Symoens (ed.), A History of the University in Europe: Vol. 2. Universities in early modern Europe (1500-1800) (Cambridge: Cambridge University Press, 1996), p. 312; Hilde De Ridder-Symoens, “The University as European Cultural Heritage: A Historical Approach.” Higher Education in Europe, 31/4 (2010): 374; Perkin, p. 170.

${ }^{12}$ Di Simone, p. 312; Perkin, p. 171; Claudia A. Zonta, “The History of European Universities: Overview and background", in Nuria Sanz and Sjur Bergan (eds.), The Heritage of European Universities (Strasbourg: Council of Europe Publishing, 2006), pp. 27-40. di Simone, 1996, p.311; Stone, p. 6.

${ }^{13}$ Robert D. Anderson, European Universities from the Enlightenment to 1914. (Oxford: Oxford University Press, 2004), p. 20. Olaf Pedersen, “Tradition and innovation" in Hilde de Ridder-Symoens (ed.), A History of the University in Europe: Vol. 2. Universities in early modern Europe (1500-1800) (Cambridge: Cambridge University Press, 1996), p. 485. Ben R. Martin, “Are Universities and University Research Under Threat? Towards an evolutionary model of university speciation”. Cambridge Journal of Economics, 36 (2012), p. 8.

${ }^{14}$ Eric. J. Hobsbawm, The Age of Revolution (London: Abacus, 1962).

${ }^{15}$ Christine Musselin, The Long March of French Universities (London: RoutledgeFarmer, 2004); Walter Rüegg, “The Europe of Universities: Their Tradition, Function of Bridging across Europe, Liberal Modernisation" in Nuria Sanz and Sjur Bergan (eds), The Heritage of European Universities (Strasbourg: Council of Europe Publishing, 2006), p. 46; De RidderSymoens, 2010, p. 376. 
Carpentier, V. (2019 forthcoming) "The History of Higher Education in Modern Europe", in J. L. Rury and E.H. Tamura (eds.) The Oxford Handbook of The History of Education, Oxford University Press, Oxford

${ }^{16}$ Robert D. Anderson, “The Idea of the University today”, History and Policy, March, www.historyandpolicy.org/papers/policy-paper-98.html. 2010; Michael. Sanderson, The Universities and British Industry 1850-1970 (London: Routledge \& Kegan Paul, 1972).

${ }^{17}$ Musselin, p. 13; G. W. Roderick and M. D. Stephens, Education and Industry in the Nineteenth Century (London: Longmans, 1978), p. 107.

${ }^{18}$ Sanderson, 2004; Brian Simon, Education and the Labour Movement (London: Lawrence and Wishart, 1965), p. 86.; Tom Steele, Knowledge is Power! The Rise and Fall of European Popular Educational Movements, 1848-1939 (Oxford: Peter Lang, 2007); Dyhouse, 2006;

Rebecca Rogers, "Learning to be Good Girls and Women: Education, Training, and Schools" in Deborah Simonton (ed.), The Routledge History of Women in Europe since 1700 (London: Routledge, 2006), p. 119.

${ }^{19}$ Sanderson, p. 231; Michael Shattock, Making Policy in British Higher Education 19452011 (Maidenhead: Open University Press, 2012); Carpentier, 2012; Peter Gosden, Education in the Second World War: A Study in Policy and Administration (London: Methuen, 1976), p. 155.

${ }^{20}$ Thomas Piketty, Capital in the 21st Century (Cambridge, MA: Harvard University Press, 2014).

${ }^{21}$ Robert Boyer and Yves Saillard, Regulation Theory: The State of the Art (London: Routledge, 2002); Louis Fontvieille and Sandrine Michel, “Analysis of the Transition between Two Successive Social Orders: Application to the Relation between Education and Growth," Review, A Journal of the Fernand Braudel Center 25/1 (2002): 23-46; Carpentier, 2012, p. 369; Michael Dobbins, Higher Education Policies in Central and Eastern Europe (Basingstoke: Palgrave Macmillan, 2011), p. 21.

${ }^{22}$ Guy Neave, "Patterns" in Walter Rüegg (ed.), A History of the University in Europe. Volume IV: Universities since 1945. (Cambridge: Cambridge University Press, 2011), p. 51. 
Carpentier, V. (2019 forthcoming) "The History of Higher Education in Modern Europe", in J. L. Rury and E.H. Tamura (eds.) The Oxford Handbook of The History of Education, Oxford University Press, Oxford

Percentages from Ulrich Teichler, "Graduation and Careers" in Walter Rüegg (ed.), A History of the University in Europe. Volume IV: Universities Since 1945 (Cambridge: Cambridge University Press, 2011), p. 321; Reay et al, 2001.

${ }^{23}$ Peter Scott, "Unified and Binary Systems of Higher Education in Europe" in Arnold Burgen (ed.), Goals and purposes of higher education in the 21st century (London and Bristol, PA: Jessica Kingsley Publishers, 1996), p. 41; Teichler, 2008, p. 361. Hans De Wit, "European Integration in Higher Education: The Bologna Process towards a European Higher Education Area" in James J. F. Forest and Philip G. Altbach (eds), International Handbook of Higher Education (Dordrecht: Springer, 2007), pp. 461-482.

${ }^{24}$ Claire Callender, “Student Numbers and Funding: Does Robbins Add Up?”, Higher Education Quarterly, 68/2 (2014): p. 180; Simon Marginson, "Higher Education and Public Good.” Higher Education Quarterly, 65 (2011): 411-433. Christophe Charle and Jacques Verger, Histoire des Universités. XIIème-XXIème siècles. (Paris : Presses Universitaires de France, 2012).

${ }^{25}$ Carpentier, 2012; Roger Brown, Higher Education and the Market (Abingdon: Routledge, 2010); Tristan McCowan, "Expansion without Equity: an Analysis of Current Policy on Access to Higher Education in Brazil”. Higher Education, 53/5 (2007): 579-598.

${ }^{26}$ Susan Robertson, Globalising UK Higher Education. LLAKES Working Paper 16. London: Institute of Education, 2010. Elaine Unterhalter and Vincent Carpentier, Global Inequalities and Higher Education (Houndmills: Palgrave/Macmillan, 2012). See also Roger King, Simon Marginson and Rajani Naidoo, A Handbook on Globalization and Higher Education (Cheltenham: Edward Elgar, 2011) and Philip Altbach and Jane Knight, "The Internationalization of Higher Education: Motivations and Realities", Journal of Studies in International Education, (2007): 290-305; Huisman and van Vught, p. 35; Jürgen Enders, 
Carpentier, V. (2019 forthcoming) "The History of Higher Education in Modern Europe", in J. L. Rury and E.H. Tamura (eds.) The Oxford Handbook of The History of Education, Oxford University Press, Oxford

Harry de Boer and Don Westerheijden (eds), Reform of Higher Education in Europe

(Rotterdam: Sense Publishers, 2011), p. 2. 